\title{
Nexus Between Board Characteristics and Corporate Financial Performance: Evidence from Sri Lanka
}

\author{
Gunaratne Y.M.C* \\ * Department of Management Sciences, Faculty of Management, Uva Wellassa University, Badulla, Sri Lanka.
}

DOI: 10.29322/IJSRP.11.12.2021.p12017

http://dx.doi.org/10.29322/IJSRP.11.12.2021.p12017

\begin{abstract}
This study endeavored to identify the nexus between the characteristics of director board and performance of corporations listed in Colombo Stock Exchange, Sri Lanka. The rationale for this study was firstly, the increasing concerns led towards the director board characteristics in corporate governance framework and secondly, the mix and controversial findings reported on the context of board characteristics of corporations and financial performance. Thus, the current study was conducted with the hypothesis of a significant relationship to be existed between board characteristics and financial performance of listed companies in Sri Lanka. Three characteristics; the board size, composition and CEO duality as the independent variables and two accounting measures, return on Assets, and Return on Equity and a market measure, Tobin's Q as the dependent variables were considered in this study. The sample consisted with 350 firm year observations comprising of seven (07) financial years' data pertaining to fifty (50) best performing non-financial companies listed in CSE. To restrict the study to the period after ending the civil war in Sri Lanka and to eliminate the impact of Easter Sunday attack and the COVID 19 global pandemic on corporate performance, the study period was limited to seven (07) years. The data were collected from the published financial statements and the CSE data library. Descriptive statistics, correlation analysis and the panel data regression analysis techniques were used for the statistical analysis. The board size indicated weak negative correlation with ROA while the board composition showed a weak positive correlation with Tobin's Q. Notably, a significant negative impact on ROA was reported if CEO duality existed while no any board characteristics exhibited statistically significant relationship with ROE. Based on the results the study concluded that the board composition and board size are less significant yet employing a single individual to perform the duties as CEO and the chairman to the board of the corporation results negative impact on its performance. Accordingly, this study recommends to occupy two proficient individuals; one in the post of CEO and another as the Chairman to the Board of directors in every public listed company in Sri Lanka to pursue higher performance.
\end{abstract}

Index Terms- Board Characteristics, CEO Duality, Corporate Governance, Financial Performance, Sri Lanka.

\section{INTRODUCTION}

$\mathrm{C}$ orporate governance is the system by which companies are directed and controlled (Cadbury, 1992). It's becoming apparently important in modern business environment as it is the commonly used tool in aligning corporate management interests with those of resource owners, to mitigate the agency problem which arises due to the separation of resource ownership from its control. Hence, a sound corporate governance mechanism is globally accepted as being fundamental to an organization's sustainable growth as well as to the capital market integrity. Corporate governance has become the focal point in $21^{\text {st }}$ century as many developed and developing economies have introduced numerous governing codes and frameworks in response to several major corporate scandals such as Enron and WorldCom collapses (Jackling and Johl, 2009) which results negative impact on stock market performance around the world. Aftermath, the corporate governance has been taken into serious attention of the researchers and policy makers and ample number of studies have been conducted particularly in the developed markets. Albeit the widespread attention and numerous research studies conducted on this phenomenon in the academic literature (James, 2019), the concept of corporate governance remains in the ongoing research agenda due to mix and controversial results reported.

The Cadbury Report (1992) highlights the crucial role played by the board of directors in governing a listed entity. As per the Code of best practice on corporate governance (CA Sri Lanka, 2017) every public company should be headed by an effective board which should direct the company to be in its appropriate agenda, execute the leadership and control the company. Additionally, the code specifically mentioned the role of the board as to act as leaders with entrepreneurial characteristics with prudent and effective controlling mechanism which can measure the organizational risk appropriately and to manage it properly (CA Sri Lanka, 2017). Further, a list of responsibilities have been specified by the code to be adhered by the board in performing assigned roles (CA Sri Lanka, 2017).

Since the board of directors of listed companies are charged with governing the resources of the entity, the prime responsibility of such board would be to work toward accomplishing the best interest of the shareholders and other investors of the entity. According to the Akpan \& Amran (2014) board of directors' main duty is to supervise the management and take accountable actions with proper justice. Jensen and Meckling (1976) argued that the board of directors to the entity should closely keep an eye on the top managements' decisions, their actions and their performance to ensure whether their activities allow to achieve the best interest 
of the actual owners. Fama and Jensen (1983) too claimed that the director board of an entity is a crucial element in corporate governance mechanism that monitor and advise management in carrying responsibility to protect shareholder interests. Working towards alleviating the agency problem is one of the other criticle role to be performed by the corporate director board (Fama (1980); Jensen (1993); Shleifer and Vishny (1997). Thus, the board of directors' role in the business is quite daunting yet a responsible role performing is undeniably important.

The director board, being the governing body of any listed entity, hold the responsibility of driving the business towards its success. The key role of any director board is to ensure the success of the organization to improve the wealth of its owners and to safeguard the interests of other stakeholders. Despite the self-interest of the director board, the shareholder and other investors expect the board to act on behalf of them to pursue the owner's maximum interest with the presumption of a goal congruence. Thus, the director board is expected to perform various essentially important tasks for organizational success. Given the increasing importance of boards, it is vitally important to identify the board characteristics that make one board more effective from another. Thus, the director board characteristics form an important element in corporate governance framework. Many scholars consider corporate board characteristics as important determinants of corporate governance ((Hermalin and Weisbach,1998, 2003), Bhagat, Carey, and Elson (1999), Brickley, Coles, and Jarrell (1997)). Though the director board characteristics on various aspects have been studying in the accounting literature for several decades in the developed countries like USA, UK, Germany, Japan etc. (Zahra and Pearce, (1989); Yermack, (1996); Hampel, (1998); Bhaget and Black, (1999); Judge, Naoumova and Koutzevol, (2003); Yoshimori (2005)), the studies regarding the corporate governance, in particular the corporate board characteristics do not provide a conclusive evidence on their relationship between each characteristic and the firm performance.

Further, in the 21 st century there has been a sharp escalation around the globe on studying corporate governance, particularly the relationship between the board characteristics and performance of corporations probably due to the increasing corporate debacles around the world. For example, among others Judge, Naoumova and Koutzevol, (2003); Abdulha, (2004); Keeling (2005); Yoshimori, (2005); Lefort and Urzúa, (2008); Jackling and Johl, (2009); Rosalina, (2010); Uadiale (2010); O'Connell and Cramer, (2010) Uwuigbe and Fakile (2012); Platt and Platt, (2012); Amin, Ifthikar \& Yasir (2013); Zulkafli \& Hamzah (2014), Topal and Dogan (2014); Johl, Kour and Cooper (2015) studied this relationship and have reported mix and controversial results in international context. This matter is similar to the Sri Lankan context too. In spite of the availability of large array of studies in search of the relationship between Board characteristic and firm performance in international context, it is hard to find any in-depth studies carried out in Sri Lankan context on the same. Hence this study endeavored to explore whether the director board characteristics have an impact on the performance of the Colombo Stock Exchange enlisted companies in Sri Lanka. Thus the current study drives towards achieving the general objective of identifying the nexus between director board characteristics and Firm performance of the CSE enlisted companies in Sri Lanka. This objective would be achieved through following three secondary objectives.

- To detect the impact of board characteristics on ROE of CSE enlisted companies in Sri Lanka

- To detect the impact of board characteristics on ROA of CSE enlisted companies in Sri Lanka

- To detect the impact of board characteristics on Tobin's Q of CSE enlisted companies in Sri Lanka

The remainder of this paper is arranged as section two; literature review, section three; methodology, section four; findings and section five; conclusion and recommendations.

\section{LITERATURE REVIEW}

The director board characteristics on various aspects have been studying by many researchers since early 1980s (Fama and Jensen, (1983); (Zahra and Pearce, (1989)). The attention on director board characteristics and its relationship with firm's financial performance was intensified due to the global financial crisis took place during mid-2007 to early-2009 after the Asian financial crisis in 1997. Many researchers for example, (Abdulha, (2004); Keeling (2005) Rosalina, (2010), Uadiale (2010); Uwuigbe and Fakile (2012); Amin, Ifthikar \& Yasir (2013); Zulkafli \& Hamzah (2014), Topal and Dogan (2014)) attempted to recognize the connection between the director board characteristics and the financial performance of corporations in various market settings worldwide. Majority of such studies were related to developed countries and less number of studies have been focused the emerging market conditions. Yet, careful analysis of the literature confirms the disagreements of the findings reported.

\section{A. The board size and firm performance}

The number of individuals included in the director board of a publicly traded company is termed as board size and there is no exact number to be in a board has being confirmed. Some scholars argue that a small in size board is better than a large size board in performance perspective while there are scholars arguing for on the large board size. Yet, an optimum board size to be maintained by a company which related with higher performance has not been identified with confirmation. However, the number of individual directors representing a director board of an entity may have influence on its performance as they are instrumental in decision making process.

Yermack, (1996), Rosalina, (2010), Uwuigbe and Fakile, (2012), and Azeez (2015) are of the opinion that small board size contributes more to the success of a company and Yermack (1996) argued that large board always slow down the decision making process and it leads to waste the valuable time.

In contrast, Goodstein et, al, (1994); Forbes and Milliken, (1999); Topal \& Dogan, (2014) findings are in favour of large board size arguing that it improves company performance as it could limit the CEO's engagement and domination, thus, it may augment the decision making effectiveness in the firm. According to the Sheikh et al., (2012) the optimal board size can vary in one firm to other based on the business. 
A positive relationship between the size of the board and the performance of the entity have been identified by many researchers in different international market settings covering both developed and emerging markets. Kula, (2005); Mak and Roush, (2000) Johl, Kaur and Cooper, (2015); among others have reported positive association of the board size of an entity with its performance indicating that a large size boards may have the capacity of intensive monitoring of activities, less CEO domination etc. Additionally, Bathula (2008) has revealed the association between board characteristics and firm performance is moderated by the size of its director board.

In contrary to the findings of scholars who reported a positive association as shown above, among others, Jenson, (1993); Yemark, (1996); John and Senbet, (1998); Azeez (2015) revealed a negative relationship between these two variables in different international market settings. These scholars' conclusions are in favorable with small size director boards as the small size boards facilitates speed of processing information (Hunter, 1997) improve the speedy and proper communication, quick decision making (John and Senbet, 1998), proper control over management (Eisenberg et al., 1998) and ability of contiguous monitoring the board engagements etc.

Based on the mix and contradictory findings on the connection available between the number of individuals (size) of a board and the firm performance in international markets as shown by the above analysis of the relevant literature, this study will explore this matter in developing country perspective for an emerging stock market.

\section{B. The CEO-Duality and firm performance}

The term CEO-Duality can be defined as the two (02) top positions in a company, the Chief Executive Officer (CEO) and the Chairman are hold by a single individual. The code of best practice on corporate governance (CA Sri Lanka, 2017) has clearly delineated two (02) crucial tasks to be performed by every public Company in order to manage the company's business and the code recommends to employ two individuals in this two positions. As per the code, to ensure appropriate balance of power and authority among its members a right division of responsibilities should be clearly specified in any public limited company. Which may result no any single individual has power to exercise undue influence over any decision. Though the code of best practice on corporate governance clearly stated that two competent individuals should hold these two positions in a company, still in Sri Lankan context as well as in international context, it is common to see the same individual is holding the both posts. However, there is no conclusive evidence to state that this dual function of a single individual results adversely to the prosperity of an organization or vice versa.

As examples, Brickley, Coles \& Jarrel (1997) argued employing a single individual in the two posts; CEO and the Chairman results undeniably an inefficiency in the particular entity. Moscu (2013) too revealed a negative impact to the performance of the entity if CEO duality exists. Corresponding to the reported results of Brickley, Coles \& Jarrel (1997) and Moscu (2013), Azeez (2015) found that a significant positive impact on firm performance if the two key tasks are assigned to two individuals.

As oppose to the above findings Abdullah, (2004) found that these two concepts do not relate to each other as the reported results of Abdullah, (2004) showed that the CEO duality is not related with the performance. In contrast, Yang \& Zhao (2011) claimed that this dual function by a single individual is beneficial for an entity's financial performance when the competition is increasing. Slightly differently, Bathula (2008) have reported the Small sized director boards are benefitted from CEO duality whereas larger sized director boards may not. The above information extracted from the literature evidenced that studying the relationship to be existed between the CEO duality and the firms performance in emerging market setting (Colombo Stock Exchange) is worthwhile.

\section{The Constitution of the Director Board and firm performance}

As per the directions of the ICASL code of best practice on corporate governance (CA Sri Lanka, 2017), having a balance between number of executive directors and number of nonexecutive directors in a company's board is recommended in order to mitigate the possible dominance by either individual or small group in company's decision making process. Further, it is recommended to have a adequate number of independent nonexecutive directors in the board. According to Stein and Plaza, (2011) the independent directors are the person who appointed on their personal and professional qualities who can perform functions without being conditioned by relationship with the company. Either the association between the ratio of independent directors and the performance or the appropriate proportion of independent directors to be in a board has not been tested yet.

As examples, Berghe and Baelden (2005) found that the independent directors are an important factor in ensuring board effectiveness. Bhagat \& Black, (1999) argued the director board must be mixed. Fama and Jensen, (1983) have mentioned that there are more studies that have found outside directors provides an effective monitoring tool for the board. Correspondingly if firm performance is poor, firms may be more or less inclined to hire outside directors (Keeling, 2005). Confirming that Nanka Bruce (2011) stated if inside directors underperform, shareholders may elect an independent dominated director board. Bulan, Yan, \& Sanyal (2009) showed a positive association between board independence and productivity while Pritchard (2009) reported that the independent directors can encourage more accurate financial reporting than others. Later Wang (2014) have reported that the existence of independent directors on the board showed a mix results on firm performance. It can be either positive, negative or no correlation. Independent directors may majorly act advisory roles, not a monitoring role in China. Furthermore, Wang (2014) revealed independent directors' characteristics have controversial effect on firm performance. Cortese and Bowrey (2007) identified independent director is more valuable than the non-executive director. Horvath \& Spirollari (2012) independent directors prefer conservation on business strategies in order to protect the shareholders, due to independent directors reduce firm performance. 
Akpan \& Amaran (2014) have controversy opinion that independent directors insignificant to corporate performance. Fuzi, Halim \& Julizarema (2016) identified relatively a large number of independent directors will not ensure improved firm performance. Thus monitoring the activities of the independent directors on the board must be ensured in order to achieve shareholder interests. Furthermore, Abdulla, (2004) and Johl, Kaur \& Cooper (2015) revealed a different result that board independence is not affecting the firm performance. As the above analysis of literature clearly demonstrate the controversial finding on this relationship particularly for international market settings, it is certain that understanding on the nexus between the board composition and the performance is required for emerging market like CSE.

\section{METHODOLOGY}

\section{A. List of Hypothesis}

Based on the extensive literature survey, the following three (03) hypothesis were developed by the researcher to achieve the objectives of this study.

H1: There is a positive association between the characteristics of the director board and ROE of the companies listed in CSE, Sri Lanka.

$\mathrm{H} 2$ : There is a positive association between the characteristics of the director board and ROA of the companies listed in CSE, Sri Lanka.

H3: There is a positive association between the characteristics of the director board and Tobin's Q of the companies listed in CSE, Sri Lanka

\section{B. Population and Sample}

Every public company enlisted in Colombo Stock Exchange (CSE) comprise the population of this study. There are 297 companies representing 20 sectors as at $31^{\text {st }}$ December 2018 . The sample of the study consisted with 50 companies out of the top 100 companies as per the LMD 100 (2016). The Bank Finance and Insurance sector companies were excluded from the sample as it is mandatory requirement for such companies to apply corporate governance in contrary to the voluntary application available for the rest of the companies. The sample period of this study spans for seven years from the financial year 2010/11 to 2016/17. The study was limited to seven years as the researcher considered only data of the post war period. Further this study was limited to period prior to the Easter Sunday attack and the global pandemic of COVID 19 which may have negative impact on firm performance.

\section{Data and data collection}

This study used secondary data for both dependent and independent variables. The required secondary data were obtained from the published financial statement of the sample companies, corporate governance disclosures, chairman's reports, CEO's and managing director's messages, and relevant other disclosures which included in the annual reports of each company considered in the sample

\section{Variable definition and calculation}

Corporate financial performance considered as the dependent variable of this study while the independent variable is financial performance of companies. As per the review of the relevant literature, Return on Equity (ROE), Return on Assets (ROA) and Tobin's Q (TQ) were considered as the proxies for corporate financial performance.

The ROE indicates the return a company is generating on the equity shareholders' investment. It was calculated by dividing the profit after tax by average shareholder's equity (Gunaratne and Anuradha, 2017). A higher ROE signposts a higher return generated on shareholders' funds. The ROA indicates the net profits earned as a percentage of total investment. It was calculated by dividing the profit after tax by average total assets. A higher ROA indicates a better utilization of company's assets in generating income. Tobin's Q is measured as the Market value of equity divided by book value of equity. It is a measure of growth prospects of the resources of an entity. To describe that the assets of a company can reflect its market value, the calculated value of Tobin's Q should be equal to 1.0. A higher Tobin's Q ratio than 1.0 indicates the market value of the entity is greater than the recorded value of assets of the entity and vice versa. Thus higher the Tobin's Q value, leads to encourage more investments in the company since it creates higher value for the investors.

The independent variable of this study is the board characteristics. Director board size, CEO duality and the Board composition were selected as board characteristics for the current study. The natural logarithm of number of individuals who represents the director board of an entity was considered as the board size. Employing a single individual for the two posts namely Chief Executive Officer (CEO) and Board Chairman is defined as CEO duality. The value of 1 and 0 were assigned for the existence of duality and for the non-existence of duality respectively. The proportion of independent directors in the board was considered as the board composition. A ratio was calculated by considering the relevant numbers.

\section{E. Statistical methods of data analysis}

Descriptive statistics, correlation analysis and panel data regression analysis techniques were used as the statistical techniques for data analysis using the Eviews software. Mean, standard deviation, maximum and minimum values were used as the descriptive statistics in this study to measure the central tendencies of the panel data set obtained and the Pearson correlation coefficient analysis was used as the bi variant analysis to measure and interpret the strength of the correlation between each two variables considered in the study.

The major analysis technique used in this study to test the hypothesis was panel data regression analysis. There are three panel data regression models, pooled panel data regression model, Fixed effect model and Random effect model. After performing all relevant diagnostic tests, the data set confirms the random effects regression model (variance components model) is the most suitable technique to be used in this study. The random effect model is appropriate for this data set due to several reasons such as it allows the researcher to include the time invariant variables in the model and it assumes that the differences available across the companies are to be random and there is no correlation with the independent variables. As it is reasonable to believe that the differences among the companies selected for the sample may have some influence on their performance, researcher accepted 
that the random effect regression model as the most appropriate data analysis model for the current study.

Accordingly, three random effect regression models were developed aligning with the hypothesis of this study, to analyze the balanced panel data set and are stated below.

ROEit $=\alpha i+\beta 1 B$ Sit $+\beta 2$ CEODit $+\beta 3$ BCit + uit $+\varepsilon i t$

ROAit $=\alpha i+\beta 1 B$ Sit $+\beta 2$ CEODit $+\beta 3$ BCit + uit + eit

TQit $=\alpha i+\beta 1 B$ Sit $+\beta 2$ CEODit $+\beta 3$ BCit + uit + eit

Where, for all regression models,

$\begin{array}{ll}\alpha & =\text { Intercept constant }(\mathrm{i}=1,2,3,4 \ldots \mathrm{n}) \\ \text { ROEit } & =\text { The return on equity of firm } \mathrm{i} \text { at time } \mathrm{t} \\ \text { ROAit } & =\text { The return on asset of firm } \mathrm{i} \text { at time } \mathrm{t} . \\ \text { TQit } & =\text { The Tobin's } \mathrm{Q} \text { of firm } \mathrm{i} \text { at time } \mathrm{t} \\ \beta 1, \beta 2, \beta 3 & =\text { Coefficients of the explanatory variables } \\ \text { BSit } & =\text { Board size of firm } \mathrm{i} \text { at time } \mathrm{t} \\ \text { CEODit = CEO duality of firm I at time } \mathrm{t} \\ \begin{array}{ll}\text { BCit } & =\text { Board composition of firm } \mathrm{i} \text { at time } \mathrm{t} \\ \text { uit } & =\text { Between entity error term } \\ \text { cit } & =\text { Within entity error term }\end{array}\end{array}$

The researcher initiated the panel data regression analysis by testing few diagnostic tests namely Levin, Lin \& Chu unit root test, Im, Pesaran \&Shin W-Stat test, ADF-Fisher Chi-Square test, test of Multy-colinearity, and Hausman Specification Test. The Levin, Lin \& Chu unit root test, Im, Pesaran \&Shin W-Stat test, ADF-Fisher Chi-Square test were used to test whether the panel data set used in this study is containing unit roots. The test of Multy-colinearity was done by the variance inflation factor (VIF) analysis. Finally, the Hausman specification test was used to select the applicable panel regression model which fits to the available panel data set of the study. Based on the results of the Hausman test the random effect regression model was selected in this study to carry on the statistical analysis

\section{RESULTS}

A. Descriptive statistics

Table 1 presents descriptive statistics of board characteristics and corporate financial performance measures.

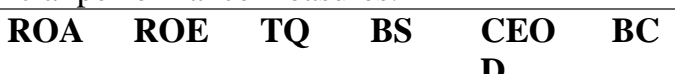

\begin{tabular}{lllllll} 
Mean & 5.289 & $\begin{array}{l}12.32 \\
0\end{array}$ & $\begin{array}{l}1.10 \\
3\end{array}$ & $\begin{array}{l}8.78 \\
8\end{array}$ & 0.416 & 0.987 \\
\hline Std. Dev. & 4.279 & $\begin{array}{l}13.67 \\
4\end{array}$ & $\begin{array}{l}0.35 \\
6\end{array}$ & $\begin{array}{l}2.03 \\
6\end{array}$ & 0.496 & 0.705 \\
Maximu & 17.75 & 61.25 & 2.02 & 12 & 1 & 3 \\
m & 0 & 0 & 0 & & & \\
\hline Minimu & - & - & 0.45 & 4 & 0 & 0.110 \\
m & 8.090 & 34.67 & 0 & & & 0 \\
& & 0 & & & &
\end{tabular}

As per the results reported in the table 01 it is notable that every performance measure considered in the study (ROE, ROA and Tobin's Q) indicate a better financial performance. The reason would be the sample selected (best performing companies) and/or the period concerned (post war era prior to the Easter Sunday attack and global pandemic of COVID 19). The Board size varies widely, from a high of 12 members to a low of 4 members. On average, there are approximately 8 members on the boards of directors. $42 \%$ of companies have appointed a single person in the post of CEO and board Chairman even though the ICASL Code recommends to employ two individuals. However most of the firms $(58 \%)$ have appointed two separate individual to undertake the Chairman's and CEO's roles separately. Further, the reported results showed that $98 \%$ of board of directors are independent directors. This results indicate that the companies listed in CSE are practicing good governance mechanisms which are recommended by the ICASL code of best practice on corporate governance.

\section{B. Correlation Analysis}

The Pearson Correlation Coefficient was used to recognize the relationship between the financial performance and the board characteristics. The results of the statistical analysis are presented in the table 2 below.

Table 2 Correlation Analysis

\begin{tabular}{|c|c|c|c|c|c|c|}
\hline $\begin{array}{l}\text { Variab } \\
\text { le }\end{array}$ & TQ & ROE & ROA & CEOD & BS & $\begin{array}{l}\text { B } \\
\text { C }\end{array}$ \\
\hline TQ & 1 & & & & & \\
\hline ROE & $\begin{array}{l}\mathbf{0 . 3 0 3} * \\
* *\end{array}$ & 1 & & & & \\
\hline ROA & $\begin{array}{l}0.467 * \\
* *\end{array}$ & $\begin{array}{l}\text { 0.692* } \\
* *\end{array}$ & 1 & & & \\
\hline CEOD & -0.060 & -0.124 & $\begin{array}{l}- \\
0.274 * \\
* *\end{array}$ & 1 & & \\
\hline BS & 0.069 & -0.089 & $\begin{array}{l}- \\
0.251 * \\
* *\end{array}$ & -0.0155 & 1 & \\
\hline BC & $\begin{array}{l}\text { 0.209* } \\
*\end{array}$ & -0.102 & -0.070 & $\begin{array}{l}\text { 0.327* } \\
* *\end{array}$ & $\begin{array}{l}- \\
0.10 \\
9\end{array}$ & 1 \\
\hline
\end{tabular}

N.B: The correlation between each pair of variables were measured at 90 percent, 95 percent and 99 percent significant levels. The resulted correlation coefficient values that are significant at 99 percent level have been marked with ***, significant at 95 percent level have been marked with $* *$ and significant at 90 percent level are marked with *

As per the reported results of the Pearson correlation coefficient analysis (presented in the table 2 above) only the board size and board composition depicted positive correlation between Tobin's $\mathrm{Q}$ and all other correlation coefficients reported are negative. However, it was observed that only board composition showed a significant correlation (weak positive) with Tobin's $\mathrm{Q}$ as the $\mathrm{P}$ value is less than 0.05 (significant at $95 \%$ significance level). Further, the reported results indicate both CEO duality and Board size have weak negative correlation with ROA at 99 percent significant level. This study found no statistically significant correlation between ROE and any of the board characteristics investigated.

\section{Panel data regression analysis}

The three models of panel data regressions were tested initially in this study. However, the pooled OLS method was rejected as it ignores the time series and cross section nature of data and the 
major drawback of using pooled OLS is it denies the heterogeneity or individuality among the 50 companies considered in the sample of the study. The fixed effect model was rejected as per the reported results of the Hausman test. Based on the Hausman test statistics, the random effect regression model was identified as the appropriate model to analyze the data of this study.

Since, the study used three proxies for the financial performances of corporations namely, ROA, ROE and Tobin's Q, three (03) random effect regression models were tested where the results are depicted in the table 3, 4 and 5 below.

Table 3 Random Effect Regression Model of ROA and Board Characteristics

\begin{tabular}{llll}
\hline Variable & Coefficient & T Statistics & Prob. \\
\hline Constant & 3.393 & 1.268 & 0.208 \\
\hline Board Size & 0.331 & 1.167 & 0.246 \\
\hline $\begin{array}{l}\text { Board } \\
\text { Composition }\end{array}$ & 0.223 & 0.295 & 0.769 \\
\hline CEO Duality & -3.625 & -3.074 & 0.002 \\
\hline$R^{2}$ & 0.123 & & \\
Prob (F-Statistic) & 0.000 & &
\end{tabular}

This table shows the results of the regression analysis conducted using panel EGLS- Estimated General Least Square (cross-section random effects) method to test the significance of director board characteristics on firm performance. As per the results of the estimated random effect regression model presented in the table 3 which was regressed on the ROA (dependent variable) with the board size, board composition and CEO duality, it was observed that only CEO duality has significant influence on firm performance at $95 \%$ significance level ( $\mathrm{P}$-value is 0.002 and the $\mathrm{t}$ Statistic is -3.074). A negative t-statistics and the negative coefficient indicates that the CEO duality negatively effect on the firm performance. Further, the adjusted R2 value is 0.123 which indicated that only $12.3 \%$ variation ROA could be explained by the overall model and as per the reported Prob (F-Statistic) it can be stated that the overall model is significant at 99 percent significant level.

Table 4 Random Effect Regression Model of ROE and Board Characteristics

\begin{tabular}{llll}
\hline Variable & Coefficient & T Statistics & Prob. \\
\hline Constant & 20.737 & 2.960 & 0.004 \\
\hline Board Size & -0.775 & -1.09 & 0.279 \\
\hline Board & -1.472 & -0.686 & 0.494 \\
Composition & & & \\
\hline CEO Duality & -3.23 & -1.055 & 0.294 \\
\hline$R^{\mathbf{2}}$ & 0.043 & & \\
Prob (F-Statistic) & 0.424 & &
\end{tabular}

As per the results of the estimated random effect regression model presented in the table 4 which was regressed on the ROE (dependent variable) with the board size, board composition and CEO duality, it was observed that no any independent variable has significant influence on firm performance as the reported tstatistics for all the variables are less than 1.96 and the P-values are greater than 0.05 (except for constant). Further, the Prob (FStatistic) is 0.424 which indicated the insignificance of the overall model. Accordingly, it can be stated that the director board characteristics are not significantly influence on the ROE of Sri Lankan companies.

Table 5 Random Effect Regression Model of Tobins'Q and Board Characteristics

\begin{tabular}{llll}
\hline Variable & Coefficient & T Statistics & Prob. \\
\hline Constant & 0.978 & 4.268 & 0.000 \\
\hline Board Size & 0.005 & 0.219 & 0.827 \\
\hline $\begin{array}{l}\text { Board } \\
\text { Composition }\end{array}$ & 0.03 & 0.515 & 0.607 \\
\hline CEO Duality & -0.051 & -0.537 & 0.592 \\
\hline$R^{2}$ & 0.006 & & \\
Prob (F-Statistic) & 0.919 & &
\end{tabular}

The table 5 illustrates the results of the regression analysis conducted using panel EGLS (cross-section random effects) method to test the significance of director board characteristics on firm performance. As per the results of the estimated random effect regression model presented in the table 5 which was regressed on the Tobins'Q (dependent variable) with the board size, board composition and CEO duality, it was observed that no any independent variable has significant influence on firm performance as the reported t-statistics for all the variables are less than 1.96 and the P-values are greater than 0.05 (except for constant). Further, the Prob (F-Statistic) is 0.919 which indicates the insignificance of the overall model. Accordingly, it can be stated that the director board characteristics are not significantly influence on the Tobins'Q of the companies listed in CSE, Sri Lanka.

\section{DISCUSSION}

The current study was conducted with the prime objective of exploring the nexus between the characteristics of the director board and the financial performance of Colombo Stock Exchange enlisted companies collecting data from top 50 companies in terms of performance, for seven financial years. Three (03) board characteristics namely the size, composition and the CEO-Duality and three financial performance measures, ROA, ROE and Tobin's Q were used in this study.

The descriptive statistical outcomes of the study demonstrated the average board size in Sri Lankan companies listed in CSE as approximately 8 . This result is in compliance with the findings of several studies in local context and in the international context in the same continent. The relationship of board size with ROA showed a week negative at $99 \%$ significant level. However, the Board Size neither with ROE nor with Tobin's Q reveled statistically significant relationship as the resultant $P$ values are greater than 0.05. As per the three random effect panel data regression models tested, it can be concluded that the board size has no statistically significant impact on financial performance of listed companies in Sri Lanka. This result is in align with Pratheepkanth, Hettihewa \& Wright (2016) who recognized the board size is not persuading ROE in Australia as well as in Sri Lankan companies; Al-Matari et al (2012) who reported an insignificant relationship of board size with Tobin's Q in Saudi Arabian listed companies. 
As per the correlation coefficient analysis, the board Composition and Tobin's Q exhibited a positive correlation at 95\% level significance though it is weak. However, the board Composition displayed neither statistically significant correlation with ROE nor with ROA. Similarly, the Board Composition revealed no statistically significant impact either on ROE or ROA or Tobin's $\mathrm{Q}$ from the panel data regression analysis. However, as per the results, the board composition depicted neither statistically significant correlation with ROE nor with ROA for Sri Lankan firms. Similarly, the Board Composition revealed no statistically significant impact either on ROE or ROA or Tobin's Q from the panel data regression analysis. The results of this study is compatible with Nazar \& Rahim (2015) who reported a statistically significant relationship of the board composition and ROE. Similarly this finding are in compatible with the results reported by Dharmadasa, Gamage \& Herath (2014) who revealed that the board composition has neither influence on ROA nor on Tobin's Q in all listed firms in CSE and Pratheepkanth, Hettihewa $\&$ Wright (2016) who argued the Board Composition has no impact either on ROA or on ROE in both Australian as well as Sri Lankan listed firms.

The CEO duality aspect is concerned, at $99 \%$ significant level it exhibited a weak negative correlation with ROA, however, neither with ROE nor with Tobin's Q. Notably, the panel data regression analysis revealed that the CEO duality has significant negative impact on ROA. However, a statistically significant impact of CEO Duality on ROE or Tobin'Q cannot be observed as the P values are not less than 0.05 of those two regression results. Duztas (2008) has reported similar result of CEO Duality and ROA. At the same time empirical analysis of Nazar \& Rahim, (2015) found CEO duality not linked both with ROA and ROE. Hewathanna, Haleem \& Jamaldeen, (2015) too revealed a weak negative relationship between CEO duality with ROA for the diversified holdings sector in CSE. A weak negative influence in CEO duality based on return on assets agreed by the Bathula (2008) in New Zealand listed firms. Dharmadasa, Gamage \& Herath (2014) revealed CEO duality neither influencing on Tobin's $\mathrm{Q}$ nor on ROA in public listed firms in CSE. Moreover, Abdullah (2004) stated CEO duality is insignificant with ROE in listed companies in Malaysia.

\section{CONCLUSION}

The aim of this study was to empirically examine the nexus between the characteristics of the board and financial performance of companies listed in CSE, Sri Lanka. To achieve this primary objective a descriptive statistics analysis, Correlation coefficient analysis and panel data regression analysis techniques were performed utilizing a data set of 350 firm year observations collected from 50 top performing companies for seven financial years. This study failed to identify a statistically significant strong relationship between director board characteristics and financial performance of listed companies in Sri Lanka. However, the board size indicated weak negative correlation with ROA while the board composition exhibited weak positive correlation with Tobin's Q. Notably the CEO Duality exhibited significant negative impact on ROA. Thus no any board characteristics exhibited statistically significant relationship with ROE.

Based on the results of the statistical analysis, this study concludes that composition of the board and its size are less significant characteristics in the perspective of firm performance of listed companies in CSE. But it is not wise to completely ignore these two characteristics as they exhibited a marginal impact on financial performance. Notably, employing a single individual for performing the two key tasks of the corporation results significant adverse impact on its performance. Henceforth, recruiting two proficient individuals is strongly recommended to the post of CEO and the Board Chairman for each listed company in Sri Lanka. further this study recommends to continuously maintaining good balance in board composition and optimum number of members in a board.

\section{REFERENCES}

[1] A.A. Azeez, "Corporate governance and firm performance: evidence from Sri Lanka", Journal of Finance, 2015, 3(1), pp.180-189.

[2] A. C. Pritchard, "Monitoring of corporate groups by independent directors." Korean Business Law. Edward Elgar Publishing, 2012.

[3] A,H. Zulkafli, and A.H. Hamzah, "Board governance and corporate financia policy". Journal of emerging issues in economics, finance and banking, 2014.

[4] B. Jackling, and S. Johl,"Board structure and firm performance: evidence from India's top companies", Corporate Governance: An International Review, 2009, Vol. 17 No. 4, pp. 492-509.

[5] C.L. Cortese, and G. Bowrey, "Profiling non-executive directors in Australia”, 2007.

[6] D. Nanka-Bruce, "Corporate governance mechanisms and firm efficiency", International Journal of Business and Management, 2011, 6(5), pp.28-40

[7] D. Nanka-Bruce, "Corporate governance mechanisms and firm efficiency. International Journal of Business and Management, 2011, 6(5), pp.28-40

[8] D. Yermack, "Higher market valuation of companies with a small board of directors". Journal of financial economics, 1996, 40(2), pp.185-211.

[9] E.F. Fama, "Agency problems and the theory of the firm", Journal of Political Economy, (1980), Vol. 88 No. 2, pp. 288-307

[10] E.F. Fama, and M.C. Jensen, "Separation of ownership and control", Journal of Law and Economics, (1983), Vol. 26 No. 2, pp. 301-325

[11] E.O. Akpan, and N.A Amran,. "Board characteristics and company performance: Evidence from Nigeria", Journal of Finance and Accounting, 2014 2(3), pp.81-89

[12] F. Lefort, and F. Urzúa, "Board independence, firm performance and ownership concentration: Evidence from Chile", Journal of Business Research, 2008, Vol. 61 No. 6, pp. 615-622

[13] G. Stein, and S. Plaza, "The role of the independent director in CEO supervision and turnover"2011.

[14] H. Bathula, "Board characteristics and firm performance: Evidence from New Zealand" (Doctoral dissertation, Auckland University of Technology), 2008.

[15] H. Platt, and M. Platt, "Corporate board attributes and bankruptcy", Journal of Business Research, 2012, Vol. 65 No. 8, pp. 1139-1143.

[16] J.A. Brickley, J.L. Coles, and G. Jarrell, Leadership structure: "Separating the CEO and chairman of the board". Journal of corporate Finance, 1997, 3(3), pp.189-220

[17] J. Hewathanna, A. Haleem, and A. Jamaldeen "The compliance of best practices of board structure and its impact for the financial performance in Sri Lanka (diversified holdings listed companies in CSE)". 5th International Symposium, SEUSL, 2015

[18] J.J. Keeling, "Cooperative Performance and Board of Director Characteristics: A Quantitative Investigation. In Selected Paper Pre-pared for Presentation at the American Agricultural Economics As-association Annual Meeting. Providence Rhode Island,2005, (pp. 23-27)

[19] J. Sheikh, W.S. Ahmed, and M. T. Masood, "Examination of Theoretical and Empirical Studies on Firm's Performance in Relation to its' Board Size: A Study of Small and Medium Size Public Firms. Journal of Management Research, 2012, 4(2), p.242. 
[20] L. Bulan, P. Sanyal, and Z. Yan, "Directors, outsiders and efficiency: An analysis of how board characteristics influence firm productivity". Journal of Economics and Business, 2009, 61(6), pp.509-528.

[21] M.C.A. Nazar, and R.A. Rahim, "Impact of corporate board size on corporate performance: evidence from Sri Lanka". Proceedings the IRES 7th International Conference, 2015

[22] M.C. Jensen, and W.H. Meckling, "Theory of the firm: managerial behavior, agency costs and ownership structure", Journal of Financial Economics, (1976), Vol. 3 No. 4, pp. 305-360.

[23] M. Yoshimori, "Does corporate governance matter? why the corporate performance of Toyota and Canon is superior to GM and Xerox", Corporate Governance: An International Review, 2005, Vol. 13 No. 3, pp. 447-457

[24] O.M. Uadiale, "The impact of board structure on corporate financial performance in Nigeria", International Journal of Business and Management, 2010, Vol. 5 No. 10, pp. 155-166

[25] O.R. Uwuigbe, and A.S. Fakile, "The effects of board size on financial performance of banks: A study of listed banks in Nigeria". International Journal of Economics and Finance, 2012, 4(2), p.260

[26] P.C. James, "Understanding the Impact of Board Structure on Firm Performance: A Comprehensive Literature Review" International Journal of Business and Social Research, 2020,10(1)

[27] P. Dharmadasa, P.Gamage, and S.K. Herath, "Corporate governance, board characteristics and firm performance: evidence from Sri Lanka" South Asian Journal of Management, 2014, 21(1), p.7

[28] P. Pratheepkanth, S. Hettihewa, and C.S. Wright, "Corporate Governance and Financial Performance: The Case of Australia and Sri Lanka". Corporate Governance, 2016, 7(1)

[29] R.G. Moscu, "Does CEO Duality Really Affect Corporate Performance?". International Journal of Academic Research in Economics and Management Sciences, 2013, 2(1), p.156.

[30] R. Horváth, and P. Spirollari, "Do the board of directors' characteristics influence firm's performance? The US evidence". Prague economic papers, 2012, 4, pp.470-486

[31] S.A. Zahra, and J.A. Pearce, "Boards of directors and corporate financial performance", Journal of Management, 1989, Vol. 15 No. 2, p. 291

[32] S. Bhagat, and B. Black, "The uncertain relationship between board composition and firm performance". The Business Lawyer, 1999, pp.921963

[33] S. Duztas, "Board characteristics, information technology maturity and transparency on company performance"2008 (Doctoral dissertation, Yeditepe University).

[34] S. F.S. Fuzi, S.A.A. Halim, and M.K. Julizaerma., "Board Independence and Firm Performance". Procedia Economics and Finance, 2016, 37, pp.460-465
[35] S. H. Awan, "Effect on board composition on firm performance: A case of Pakistan listed companies". Interdisciplinary Journal of Contemporary Research in Business, 2012, 3(10), pp.853-863

[36] S.K. Johl, S. Kaur,and B.J. Cooper, "Board characteristics and firm performance: Evidence from Malaysian public listed firms". Journal of Economics, Business and Management, 2015, 3(2), pp.239-243

[37] S. N. Abdullah, "Board composition, CEO duality and performance among Malaysian listed companies", Corporate Governance, 2004, Vol. 4 No. 4, pp. 47-61.

[38] S. Rosalina, "Board Size, Board Composition, and Property Firm Performance" 2010 .

[39] T. Yang, and S. Zhao, "CEO duality and firm performance: Evidence from an exogenous shock to the competitive environment". Journal of Banking \& Finance, 2011, 49, pp.534-552.

[40] V. O'Connell, and N. Cramer, "The relationship between firm performance and board characteristics in Ireland", European Management Journal, 2010, Vol. 28 No. 5, pp. 387-399.

[41] W. Judge, Q. Naoumova, and N. Koutzevol, "Corporate governance and firm performance in Russia: an empirical study", Journal of World Business, 2003,Vol. 38 No. 4, pp. 385-396

[42] Y.A. Al-Matari, A.K. Al-Swidi, F.H.B. Fadzil, H. Fadzil, andE,M, AlMatari, "Board of directors, audit committee characteristics and the performance of Saudi Arabia listed companies". International Review of Management and Marketing, 2012, 2(4), p.241

[43] Y.M.C. Gunaratne, and P.A.N.S. Anuradha, "Value Rerevance of Accounting Information in Explaining Stock Returns In Sri Lanka", International Journal of Business and Management; 2017, Vol. 12, No. 10; 2

\section{AUTHORS}

First Author - Yathra Mullage Chithrasheeli Gunartne, Bsc. Management, MSc. Management, Certified Business Accountant, Senior Lecturer, Department of Management Sciences, Uva Wellassa University of Sri Lanka, chithrasheeli@uwu.ac.lk / gunaratneymc@gmail.com

Correspondence Author - Yathra Mullage Chithrasheeli Gunartne, chithrasheeli@uwu.ac.lk/gunaratneymc@gmail.com Author name, email address, alternate email address (if any), contact number. 